Canadian

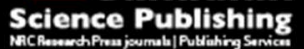

Canadian Journal of Civil Engineering Revue canadienne de génie civil

\title{
Laboratory Characterization of Reclaimed Asphalt Pavement for Road Construction in Egypt
}

\begin{tabular}{|r|l|}
\hline Journal: & Canadian Journal of Civil Engineering \\
\hline Manuscript ID & Cjce-2016-0435.R1 \\
\hline Manuscript Type: & Article \\
\hline Date Submitted by the Author: & 05-Jan-2017 \\
\hline Complete List of Authors: & $\begin{array}{l}\text { Mousa, Eman; Mansoura University Faculty of Engineering, Public Work } \\
\text { Engineering } \\
\text { Azam, Abdelhalim; Mansoura University Faculty of Engineering, Public } \\
\text { Works Engineering } \\
\text { El-Shabrawy, Mohamed; Mansoura University Faculty of Engineering, public } \\
\text { Works engineering } \\
\text { El-Badawy, Sherif; Mansoura University Faculty of Engineering }\end{array}$ \\
\hline Keyword: & $\begin{array}{l}\text { reclaimed asphalt pavement, resilient modulus, load duration, } \\
\text { permeability, California Bearing Ratio }\end{array}$ \\
\hline \multicolumn{2}{|c}{} \\
\hline
\end{tabular}




\title{
Laboratory Characterization of Reclaimed Asphalt Pavement for Road Construction in Egypt
}

\author{
E. Mousa ${ }^{1}$, A.M., Azam $^{2}$, M., El-Shabrawy ${ }^{3}$, and S. M., El-Badawy ${ }^{4}$ \\ ${ }^{1}$ Master Student, Public Works Engineering Department, Faculty of Engineering, Mansoura \\ University, Egypt. Email: Eman mosa89@yahoo.com \\ ${ }^{2}$ Assistant Professor, Mansoura University, Public Works Eng. Dept., Faculty of Engineering, \\ Mansoura University, Mansoura, Egypt. E-mail: Abdelhalim.Azam@mans.edu.eg \\ ${ }^{3}$ Professor, Mansoura University, Public Works Eng. Dept., Faculty of Engineering, \\ Mansoura University, Mansoura, Egypt. E-mail: mshabrawy@mans.edu.eg \\ ${ }^{4}$ Associate Professor, Mansoura University, Public Works Eng. Dept., Faculty of Engineering, \\ Mansoura University, Mansoura, Egypt. E-mail: sbadawy@mans.edu.eg
}




\begin{abstract}
This paper presents the engineering characteristics of reclaimed asphalt pavement, blended with virgin aggregate for unbound base/subbase layers. The proportions of RAP were $0 \%, 20 \%, 60 \%, 80 \%$ and $100 \%$ by total mass of the blend. The experimental laboratory testing included index properties such as gradation, modified Proctor compaction, California Bearing Ratio, and hydraulic conductivity. Repeated load resilient modulus testing was conducted on the blends. The impact of load duration on resilient modulus was also investigated. A strong inverse trend was found between resilient modulus and California Bearing Ratio. An accurate model was proposed for the prediction of the resilient modulus as a function of stress state and reclaimed asphalt pavement percentage with coefficient of determination of 0.94 . Finally, multilayer elastic analysis of typical pavement sections with the base layer constructed of virgin aggregate- reclaimed asphalt pavement blends showed good performance.
\end{abstract}

Keywords: reclaimed asphalt pavement, resilient modulus, load duration, permeability, California Bearing Ratio.

\title{
Introduction
}

Massive quantities of waste materials are accumulating in stockpiles and landfills throughout the world. These materials result in financial and environmental problems. Recycling of demolition debris into new construction projects offers a mean for reduction of waste disposal loads accumulating in landfills and preservation of the natural resources. Numerous recycled materials such as reclaimed asphalt pavement (RAP), crushed waste rock, crushed glass, recycled concrete aggregate (RCA) and recycled clay masonry (RCM) may be used as pavement materials (Dong and Huang 
2014; Azam and Cameron 2013; Wu et al. 2012; Ayan 2011; Gupta et al. 2009; McGarrah 2007; Kim et al. 2007; Mokwa et al. 2005; Bennert et al. 2000; Taha et al. 1999).

In Egypt, large quantities of waste materials are generated especially with the rapid population growth, economy growth, and continuously increasing consumption. The Egyptian market produces approximately 4 million tons of RAP per year due to continuous pavement milling or scraping processes (Behiry et al. 2015). The fees allocated to waste handling vary considerably from project to another. In Egypt, it is estimated to be about $0.5 \%$ to $7.5 \%$ of the overall project cost (Kamel 2007). RAP is a potential substitute for natural aggregate. Although the application of RAP as a pavement material was well investigated internationally, it is a new practice in Egypt. Only few studies addressed it and these studies were only based on simple index properties of the materials such as the CBR (Alotaibi et al. 2010; Behiry et al. 2015). Most of the empirical equations that correlated the CBR values of unbound granular materials with the resilient modulus were based on testing results of virgin aggregates. It is believed that no equations are available, so far, for the recycled products, especially RAP. In general, with the increase of the CBR values, the resilient modulus of unbound granular materials increases. However, the opposite is true for the RAP materials, i.e., $M_{r}$ increases while the CBR decreases (Bennert and Maher 2005).

Furthermore, limited literature studies investigated the impact of load cycle duration on the resilient behavior of the unbound granular materials and reported a little effect (Seed et al. 1965; Hicks 1970; Thom and Brown 1987). None of these studies investigated the impact of load duration on the recycled materials specially RAP which contains asphalt. Asphalt is a viscous material which is expected to be affected by the load duration. 
The main objective of this study is to conduct a comprehensive laboratory characterization including the investigation of the resilient behavior of different RAP percentages blended with virgin aggregate under repeated load tests. The specific objectives of the study are to: 1) evaluate the feasibility of RAP/virgin aggregate blends as a base/subbase material in pavement construction in Egypt; 2) develop a universal model for resilient modulus prediction of the blends; 3) investigate the effect of loading time cycle and bitumen content on $\mathrm{M}_{\mathrm{r}}$ of the blends, and finally 4) propose a simple relationship between $\mathrm{CBR}$ and resilient modulus for the RAP blends.

\section{Literature Review}

Over years, numerous studies have been performed to evaluate the mechanical and physical properties of the RAP for pavement construction. (Sayed et al. 1993; Garg and Thompson 1996; Mokwa and Peebles 2005; Alam et al. 2010; Sayed et al. 2011 and Dong and Huang 2014) evaluated the use of RAP as a base material. The evaluation was based on field sections constructed with different types of aggregate and RAP as base layers. The authors reported equivalent performance of the RAP, lime-rock base, and a conventional crushed stone.

(Taha et al. 1999) evaluated RAP and virgin aggregate blends as road base and subbase layers. Gradation, compaction, and California Bearing Ratio (CBR) tests were performed on RAP/aggregate blends of $0 \%, 20 \%, 40 \%, 60 \%, 80 \%$ and $100 \%$. The results showed that the $100 \%$ RAP had the lowest strength, with a CBR value of $11.0 \%$. Based on CBR evaluation, they recommended that blends containing $60 \%$ or less RAP are suitable as subbase layers. However, blends with only $10 \%$ RAP can be used as base material. 
Several studies reported that the CBR of RAP and virgin aggregate blends, decreased with the increase of RAP percentage in the blend (Ayan 2011; McGarrah 2007; Bennert and Maher 2005; Taha et al. 1999; Sayed et al. 1993).

(Wu 2011; Alam et al. 2010); Gupta et al. 2009; Kim et al. 2007; Bennert et al. 2000) investigated the effect of RAP percentage on the resilient modulus $\left(\mathrm{M}_{\mathrm{r}}\right)$ of blends of RAP with virgin aggregate. In general, the RAP percentage in the blends varied from $0 \%$ to $100 \%$ by total mass of the blend. The main finding of these studies is that the increase of RAP replacement level in the blend, yielded an increase in resilient modulus.

Permeability is an important property of the base material. (Trzebiatowski et al. 2005) investigated the hydraulic conductivity of RAP as a base material. They found that the RAP hydraulic conductivity ranged from $4.5 \times 10^{-8}$ to $1.7 \times 10^{-6} \mathrm{~m} / \mathrm{s}$. These permeability values are similar to the permeability of traditional granular base materials. In similar studies, (Macgregor et al. 1999; Gupta et al. 2009) evaluated the hydraulic conductivity of blends of RAP and crushed-stone aggregate. The authors found that the RAP percentage in the blend did not significantly affect the hydraulic conductivity. Conversely, (Wu et al. 2012; Bennert and Maher 2005) noted that the permeability of a base material decreased as the RAP percentage in the blend increased. These studies reveal significantly different permeability values of the RAP/aggregate blends.

\section{Materials}

RAP was sourced from a major road in Port Said governorate, Egypt which was under rehabilitation. A cold milling machine was used to produce the RAP. The asphalt content in the RAP material was determined by the centrifuge extraction according to 
(AASHTO T 164-97 2002), (Method A). The results indicated that the average bitumen content was $5.2 \%$ by weight of the mix.

The virgin aggregate was crushed dolomite supplied from Ataqa quarry in Suez governorate, Egypt. The RAP was blended with the virgin aggregate in the laboratory with percentages of $0 \%, 20 \%, 40 \%, 60 \%, 80 \%$ and $100 \%$ by total mass of the blend.

\section{Experimental Testing Program}

The laboratory testing program included the basic engineering properties and performance tests. The basic properties are the particle size distribution, specific gravity, water absorption, Los Angeles Abrasion (LAA), Atterberg limits (Liquid Limit, LL - Plasticity Index, PI), modified Proctor compaction, CBR, Potential of Hydrogen $(\mathrm{pH})$ and hydraulic conductivity. The performance test is the Repeated Load Triaxial Test (RLTT) which was performed to evaluate the resilient modulus of the blends.

\section{Basic Engineering Properties}

The particle size distribution was conducted on the RAP and virgin aggregate materials in accordance with (AASHTO T 27-99 2012). Figure 1 presents the gradation curves of the RAP and virgin materials along with the upper and lower limits of the Egyptian specifications for the base material (ECP-104. 2008). It can be seen from the figure that the gradation curve of the virgin aggregate is within the limits. However, as expected, the gradation of the RAP was outside the specification limits.

Table 1 presents the basic engineering properties of the blends. It can be noted that the specific gravity values decreased with the increase in the percentage of the RAP 
replacement in the blend. This is due to the presence of the asphalt which has a specific gravity less than that of the aggregate.

Data in Table 1 also show that the water absorption, LL, PI and LAA results for the RAP and virgin aggregates comply with the Egyptian standards for the base materials (ECP-104. 2008). The RAP was found to be non-plastic and seems to have abrasion resistance less than the virgin aggregate.

The $\mathrm{pH}$ values for RAP and virgin aggregate were 9.5 and 7.8 , respectively which indicated that the RAP is more alkaline than the neutral level of deionized water of $\mathrm{pH}$ equals 7. This also indicated that corrosion of samples was moderate.

As indicated in Table 1 the maximum dry density (MDD) tends to decrease as the level of RAP replacement in the blend increases however, the optimum moisture content $(\mathrm{OMC})$ in general was found to decrease with increase in the RAP percentage. This may be attributed to the very low moisture holding capability of RAP due to the asphalt coated aggregate in the RAP. Thus, the addition of virgin aggregate would make it much easier to compact RAP as a base material (Taha et al. 1999).

In general, the soaked CBR values dramatically decreased with the increase of RAP content in the blend. This may be owing to the reduction in the angle of internal friction of the mixture due to the asphalt-coated particles of the RAP (Alotaibi et al. 2010). Furthermore, the RAP-Aggregate blends have lower fines content compared to the virgin aggregate. This may lead to further decrease in the shear strength of the blend.

The Egyptian specifications require a minimum soaked CBR value of $80 \%$ for the base layer of major roads, whereas a CBR value of $60 \%$ is the minimum acceptable 
value for minor and local roads (ECP-104. 2008). Consequently, the blend containing $20 \%$ RAP can be used as a base material for minor roads and the blends containing up to $60 \%$ RAP can be used as a subbase material (the required value ranges from $25 \%$ to $40 \%$ depending on the functional class of the road(ECP-104. 2008).

Table 1 also presents the hydraulic conductivity values for all blends. In general, the permeability of the blends increased with the decrease of RAP content. The results indicate that adding RAP yields lower porosity (interconnected voids) in the specimen.

\section{Resilient Modulus Testing}

The resilient modulus is an important input parameter for the flexible pavement thickness design according to the Mechanistic Empirical Pavement Design Guide (MEPDG), and the American Association of State Highway and Transportation Officials (AASHTO 1993) design method. Resilient modulus testing was conducted according to the (AASHTO T 307-99 2012). The test protocol for base and subbase materials consists of a pre-conditioning sequence and 15 loading sequences. The number of load repetitions is 500 cycles for the conditioning stage and 100 cycles for each loading sequence. Different combinations of confining pressure and cyclic stress are applied. The confining pressure ranges from 20.7 to $137.9 \mathrm{kPa}$, while the cyclic stress varies from to 18.6 to $248.2 \mathrm{kPa}$. The loading shape is a haversine of 0.1 -second load pulse followed by a 0.9 -second rest period (one cycle duration $=1$ second).

All specimens were prepared using a split mold of $150 \mathrm{~mm}$ diameter and $300 \mathrm{~mm}$ height and compacted in 6 layers, with 114 blows to each layer according to the modified compaction effort. Duplicate samples were prepared for each blend at the MDD and OMC. 
The specimen was placed on the bottom plate of the load cell and the rubber membrane was stretched around the specimen by the membrane expander and then the membrane was sealed to the end caps by means of O-rings. Two external linear variable differential transducers (LVDTs) were mounted of the triaxial cell.

The resilient modulus was performed using the Universal Testing Machine (UTM-25) at the Highway and Airport Engineering Laboratory (H\&AE-LAB), Faculty of Engineering, Mansoura University, Egypt. The resilient modulus was calculated as the average of the last five cycles of each sequence.

\section{Results and Discussion}

As expected, the resilient modulus increased with the increase of bulk stress. $\mathrm{M}_{\mathrm{r}}$ also increased with the increase in the amount of RAP in the blend. This indicates that the addition of RAP resulted in a stiffer mixture due to the presence of the asphalt in the RAP. With the addition of more RAP to the blend, the amount of binder increases, resulting in an increase in the modulus. This observation complies with the findings of (MacGregor et al. 1999); Bennert et al. 2000; Wu 2011).

The dataset from testing results was fitted with the universal model shown by Equation 1 (ARA, 2004).

$M_{r}=K_{1} p_{a}\left(\frac{\theta}{p_{a}}\right)^{k 2}\left(\frac{\tau_{o c t}}{p_{a}}+1\right)^{k 3}$

where:

$$
\begin{aligned}
& \mathrm{M}_{\mathrm{r}}=\text { Resilient modulus, } \mathrm{MPa} \\
& \theta=\text { Bulk stress }=\sigma_{1}+\sigma_{2}+\sigma_{3}, \mathrm{kPa}
\end{aligned}
$$




$$
\begin{aligned}
& \sigma_{1}=\text { Major principal stress, } \mathrm{kPa} \\
& \sigma_{2}=\text { Intermediate principal stress, } \mathrm{kPa} \\
& \sigma_{3}=\text { Minor principal stress, } \mathrm{kPa} \\
& \tau_{\mathrm{oct}}=\text { Octahedral shear stress }=\frac{\sqrt{(\sigma 1-\sigma 2)^{2}+(\sigma 1-\sigma 3)^{2}+(\sigma 2-\sigma 3)^{2}}}{3}, \mathrm{kPa} \\
& \mathrm{p}_{\mathrm{a}}=\mathrm{Atmospheric} \text { pressure }=101 \mathrm{kPa} \\
& \mathrm{K}_{1}, \mathrm{k}_{2}, \mathrm{k}_{3}=\text { Material constants }
\end{aligned}
$$

The data yielded adjusted coefficient of determination $\left(\mathrm{R}_{\mathrm{adj}}{ }^{2}\right)$ that ranged from 0.90 to 0.97 for the different blends indicating "excellent" goodness of fit. The regression parameters of the universal model for all tested blends are shown in Table 2 along with the standard error of estimate/standard deviation of the laboratory measured values $\left(\mathrm{S}_{\mathrm{e}} / \mathrm{S}_{\mathrm{y}}\right), \mathrm{R}_{\mathrm{adj}}{ }^{2}$, and root mean square error (RMSE) which were determined using Equations 2, 3 and 4.

$S_{e} / S_{y}=\sqrt{\frac{\sum\left(x_{\text {pred }}-x_{\text {meas }}\right)^{2} \times(n-1)}{\sum\left(x_{\text {meas }}-x_{\text {avg }}\right)^{2} \times(n-p)}}$

$$
R_{a d j}^{2}=1-\left[\left(\frac{n-1}{n-p}\right) \times\left(\frac{s_{e}}{s_{y}}\right)^{2}\right]
$$

$R M S E=100 \sqrt{\frac{\sum\left(\left(x_{\text {pred }}-x_{\text {meas }}\right) / x_{\text {pred }}\right)^{2}}{n}}$

where:

$$
\begin{aligned}
& \mathrm{x}_{\text {pred }}=\text { Predicted } \mathrm{M}_{\mathrm{r}} \\
& \mathrm{x}_{\text {meas }}=\text { Measured } \mathrm{M}_{\mathrm{r}} \\
& \mathrm{x}_{\mathrm{avg}}=\text { Average of } \mathrm{x}_{\text {pred }}
\end{aligned}
$$




$$
\begin{aligned}
& n=\text { Number of data sets }\left(M_{r} \text { measurements }\right) \\
& p=\text { Number of regression parameters }
\end{aligned}
$$

The application of the universal model for the whole dataset for all blends yielded a low $\mathrm{R}_{\mathrm{adj}}{ }^{2}$ of 0.369 , high $\mathrm{S}_{\mathrm{e}} / \mathrm{S}_{\mathrm{y}}$ of 0.790 and high RMSE of 38.92 (refer to Table 2). The resilient moduli were calculated at the anticipated field stresses for a base layer using the universal resilient modulus model (Equation 1) and the regression parameters in Table 2. The reported anticipated field deviator stress for the unbound granular materials is in the range of 89.7 to $110.4 \mathrm{kPa}$ while the anticipated confining pressure ranges from 27.6 to $55.2 \mathrm{kPa}$ (Ji et al. 2014).

The effect of RAP percentage in the blend on the resilient modulus was studied. The calculated resilient modulus at the anticipated field stresses $\left(\sigma_{\mathrm{d}}=110.4 \mathrm{kPa}\right.$ and $\sigma_{3}=$ $55.2 \mathrm{kPa}$ ) for each blend is depicted in Figure 2. A strong linear trend was found between the RAP percentage and the resilient modulus confirming that the RAP level in the blend has a significant effect on the resilient modulus. This is also indicated by the values of the term $k_{1}$ of the universal model (Equation 1) which is found to increase with the increase of RAP percentage in the blend as shown in Table 2.

The values of the resilient modulus for different blends were compared with the South Australian Department for Transport, Energy and Infrastructure standards for the recycled material (DPTI 2011) as currently there are no Egyptian standards for the resilient modulus. All the blends meet the requirements for base material which is 300 $\mathrm{MPa}$ as a minimum.

\section{Resilient Modulus Model Development}

\section{Significance of RAP percentage}


A model is proposed for resilient modulus prediction based on the universal model with a single set of constants for all blends. As discussed before, the effect of the RAP percentage on the resilient modulus is obvious. Consequently, the proposed model considers this effect. The proposed model is shown in Equation 5.

$M_{r}=k_{1} p_{a}\left(\frac{\theta}{p_{a}}\right)^{k_{2}}\left(\frac{\tau_{o c t}}{p_{a}}+1\right)^{k_{3}}+k_{4} R A P$

Where:

$\mathrm{RAP}=\mathrm{RAP}$ percentage in the blend $(\%)$

$\mathrm{k}_{1}, \mathrm{k}_{2}, \mathrm{k}_{3}, \mathrm{k}_{4}=$ regression parameters $=1.44,0.60,0.192,4.10$, respectively (See Table 2).

Figure 3 presents the dataset fitted with the proposed model (Equation 5) which indicates excellent goodness of fit with $\mathrm{R}_{\text {adj }}^{2}$ of $0.94, \mathrm{~S}_{\mathrm{e}} / \mathrm{S}_{\mathrm{y}}$ of 0.236 , and RMSE of $12.24 \%$. It is interesting that the value of the regression parameter $\left(\mathrm{k}_{4}\right)$ in Equation 5 has the same value of the slope of the $\mathrm{M}_{\mathrm{r}}$-RAP relationship shown in Figure 2.

\section{Significance of load duration and Bitumen Content}

The blends of $20 \%$ and $60 \%$ RAP were chosen to investigate the load duration impact on the modulus. The cycle duration was changed from 1 second to 2 seconds and 3 seconds. These load durations represent the slow speeds at the highway intersections and during traffic jams. The cycle duration of 2 seconds was divided into 0.5 second loading and 1.5 second dwell, whereas the 3 seconds cycle duration was divided into 1 second loading time and 2 seconds dwell.

The significance of the cycle duration $(1,2$, and 3 seconds) on the resilient modulus was studied for the $20 \%$ and $60 \%$ RAP blends. Figure 4 exemplifies the effect of load 
duration on the $60 \%$ RAP blend over the 15 load sequences. This figure shows that the resilient modulus decreases with the increase in loading time. This indicates that with an increase in loading time, RAP/aggregate blends will deform rapidly.

Figure 5 presents the average calculated resilient modulus at the anticipated field stresses and different cycle durations for the $20 \%$ and $60 \%$ RAP blends. The results show that as the percentage of RAP in the blend increases from $20 \%$ (i.e., $1.04 \%$ asphalt content by total weight of the blend) to $60 \%$ (i.e., $3.12 \%$ asphalt content), the effect of load duration increases. This is clear from the slopes of the regression lines shown in Figure 5. The reason for that is the viscoelastic behavior of the asphalt material; i.e., RAP behaves as elastic material at the fast moving loads while it behaves as a viscous material at slow moving loads (Khan et al. 2015).

Further validation of the proposed model (Equation 5) was made using the testing results at different cycle durations. The data was divided into two parts (2 seconds and 3 seconds cycle duration). By the optimization of the model for each case, the proposed model gave an excellent goodness of fit. The regression parameters and goodness of fit statistics are summarized in Table 2.

It should be noted that the proposed model is limited to one moisture state and density, therefore, further validation of the model over a range of moisture states and densities should be considered in the future.

Another model is proposed for resilient modulus prediction based on the universal model with a single set of constants for all blends taking into account the load duration. The proposed model is given by Equation 6 .

$$
M_{r}=(a t+b) p_{a}\left(\frac{\theta}{p_{a}}\right)^{k_{2}}\left(\frac{\tau_{o c t}}{p_{a}}+1\right)^{k_{3}}+k_{4} R A P
$$


Where:

$\mathrm{t}=$ load cycle duration $(\mathrm{sec})$

$\mathrm{a}, \mathrm{b}, \mathrm{k}_{2}, \mathrm{k}_{3}, \mathrm{k}_{4}=$ regression parameters $=-0.35,1.84,0.62,0.34,2.42$, respectively.

Figure 6 presents the dataset fitted with the proposed model (Equation 6). The model yielded excellent goodness of fit statistics with $\mathrm{R}_{\text {adj }}^{2}$ of $0.917, \mathrm{~S}_{\mathrm{e}} / \mathrm{S}_{\mathrm{y}}$ of 0.285 , and RMSE of $19.87 \%$.

\section{$M_{r}$ and CBR Relationship}

Table 3 presents some of the previous models that have been reported to estimate the resilient modulus from $C B R / b u l k$ and or octahedral shear stress. The estimated $M_{r}$ values for the investigated RAP blends from these models are also presented. A comparison was made between the estimated $\mathrm{CBR}$ and the calculated $\mathrm{M}_{\mathrm{r}}$ based on the anticipated field stresses. This comparison indicated a significant difference between the estimated and calculated $\mathrm{M}_{\mathrm{r}}$ values. The difference between the values increases as the RAP percentage in the blend increases, because these empirical equations were developed for virgin aggregates not RAP. It should be noted that Equation (7) in the table is used in the MEPDG software to estimate the resilient modulus from CBR in level 2 unbound materials inputs (ARA, 2004). (Abd El-hakiem et al. 2016) reported that the application of Equation (7) in the MEPDG for recycled materials was not reasonable. Thus a new equation should be developed and calibrated for recycled materials.

Figure 7 demonstrates the relationships between $\mathrm{M}_{\mathrm{r}}$ and $\mathrm{CBR}$ for all blends. It can be seen that the resilient modulus is inversely proportional with the CBR. A strong power trend was found between the $M_{r}$ and CBR in this study with $R^{2}$ equals 0.93 . The first 
model (Equation 10) is based on $\mathrm{M}_{\mathrm{r}}$ values calculated at the anticipated field stresses using the k- $\theta$ model (Equation 9) while Equation 11 is based on $\mathrm{M}_{\mathrm{r}}$ values calculated at the anticipated field stresses using the universal model (Equation 1). In both equations, $\mathrm{M}_{\mathrm{r}}$ is expressed in MPa while the CBR is expressed in percentage.

$$
\begin{aligned}
& M_{R}=1400(C B R)^{-0.32} \\
& M_{R}=1392.36(C B R)^{-0.31}
\end{aligned}
$$

Only very few literature studies tested RAP blends for both CBR and $\mathrm{M}_{\mathrm{r}}$. (Bennert and Maher 2005; Kolay and Singh 2016) conducted the CBR and $\mathrm{M}_{\mathrm{r}}$ testing on different RAP/virgin aggregate blends prepared at OMC and MDD. In this paper, the results of these two studies were used to develop $M_{r}-C B R$ relationships. A comparison between these relationships and the proposed $\mathrm{M}_{\mathrm{r}}-\mathrm{CBR}$ relationship of this study (Equation 11) is shown in Figure 7. It is clear from this comparison that the $\mathrm{M}_{\mathrm{r}}-\mathrm{CBR}$ relationship depends on the source material properties. In order to develop a universal $\mathrm{M}_{\mathrm{r}}-\mathrm{CBR}$ relationship, more RAP/aggregate blends from different sources need to be tested.

\section{Evaluation of Pavement Life using KENLAYER}

The pavement service life was predicted using the KENLAYER software (Huang, 2004). A typical flexible pavement section with 5 in. $(12.7 \mathrm{~cm})$ asphalt layer on top of 10 in. $(25.4 \mathrm{~cm})$ base layer resting on a subgrade as demonstrated in Figure 8 was used in the simulation runs. The RAP blends $(0 \%$ and $20 \%$, and $100 \%)$ were used as base layer. The main properties of the base materials are summarized in Table 4 . The properties of the asphalt and subgrade layers are the same for all sections as shown in Figure 8 . 
Traffic repetitions of 50,000 18-kips $(80-\mathrm{kN})$ equivalent single axle loads (ESALs) per year, with 120 psi $(0.827 \mathrm{MPa})$ tire pressure and 13 in. $(33 \mathrm{~cm})$ spacing between the dual tires were applied to the studied pavement sections. The nonlinear analysis module for the base layer was used in the analysis. This module uses the k- $\theta$ model (Equation 9) to express the nonlinear properties of the base layer. The parameters were input into KENLAYER program for damage analysis based on the three-layered pavement systems under the standard axle load with dual tires presented previously. The damage analysis was based on the horizontal tensile strain at the bottom of the asphalt layer for fatigue failure and the vertical compressive strain at the top of the subgrade layer for rutting failure. The service lives of the analyzed pavements were found to be $18.6,23.6$ and 93.7 years for $0 \%, 20 \%$ and $100 \%$ RAP, respectively. This analysis confirms the validity of RAP as a base material. It shows that RAP is a superior material compared to virgin aggregate in base layers. However, for the higher percentage of RAP i.e. $100 \%$ RAP, permanent deformation testing is recommended to be performed on these materials. The use of a CBR as the main criterion for the selection of the unbound materials for base and subbase layers, which is being practiced by many countries, should be further investigated for the RAP.

\section{Conclusions}

Based on the testing results and analyses, it was indicated that the CBR and the hydraulic conductivity decreased with the increase of the RAP percentage. However, a dramatic increase in resilient modulus values was noted with the increase of the RAP replacement in the blend for samples compacted at OMC and MDD. Based on CBR results, RAP up to $60 \%$ can be used in road subbase construction in Egypt. However, only up to $20 \%$ RAP could be used in road base construction. This is based 
only on the CBR as the sole criterion for the RAP strength. However, this criterion is questionable for the RAP and should be further investigated. A model was proposed for the prediction of resilient modulus as a function of the stress state and RAP amount. The model provides excellent prediction of resilient modulus with $\mathrm{R}^{2}$ of 0.94 . It was also indicated that the resilient modulus decreases with increase in load cycle duration, which indicates that with increase in time of loading, the deformation will be rapid. Another model was proposed for resilient modulus prediction based on the universal model with a single set of constants $\left(\mathrm{R}^{2}=0.92\right)$ for all blends taking into account the load duration. A strong inverse trend was found between $M_{r}$ and CBR. Finally, an $\mathrm{M}_{\mathrm{r}}$-CBR relationship was proposed for the investigated RAP materials. This relationship depends on the properties of the source materials. The nonlinear multilayer elastic analysis using KENLAYER showed superior performance of pavement sections with base layers of $100 \%$ RAP compared to only virgin aggregate base layers. However, permanent deformation testing is important to justify the results of the $100 \%$ RAP materials. Finally, more investigation should be conducted on different recycled materials for more clarification on the impact of the load duration on resilient modulus.

\section{ACKNOWLEDGMENTS}

The authors would like to acknowledge the HEI Labs Accreditation Project (HLAB), $7^{\text {th }}$ Cycle for the fund used to purchase the UTM-25 at Mansoura University H\&AE LAB. 


\section{References}

AASHTO T 307-99. 2012. Determining the resilient modulus of soils and aggregate materials. American Association of State Highway and Transportation Officials, Washington, DC, USA.

AASHTO T 96-99. 2012. Resistance to degradation of small-size coarse aggregate by abrasion and impact in the los angeles machine. American Association of State Highway and Transportation Officials, Washington, DC, USA.

AASHTO T 27-99. 2012. Sieve Analysis of fine and coarse aggregates. American Association of State Highway and Transportation Officials, Washington, DC, USA. AASHTO M 145-91. 2012. Classification of soils and soil-aggregate mixtures for highway construction purposes. American Association of State Highway and Transportation Officials, Washington, DC, USA.

AASHTO T 193-99. 2003. The california bearing ratio. American Association of State Highway and Transportation Officials, Washington, DC, USA.

AASHTO T 180-97. 2012. Moisture-density relations of soils using a 4.54-kg (10-ib) rammer and a 457-mm (18-in.) drop. American Association of State Highway and Transportation Officials, Washington, DC, USA.

AASHTO T 164-97. 2002. Quantitative extraction of bitumen from bituminous paving mixtures. American Association of State Highway and Transportation Officials, Washington, DC, USA.

AASHTO T 85-91. 2012. Specific gravity and absorption of coarse aggregate. American Association of State Highway and Transportation Officials, Washington, DC, USA.

AASHTO T 89-96. 2014. Determining the liquid limit of soils. American Association of State Highway and Transportation Officials, Washington, DC, USA. 
AASHTO T 90-00. 2015. Determining the plastic limit and plasticity index of soils. American Association of State Highway and Transportation Officials, Washington, DC, USA.

AASHTO T 289-91. 2008. Determining pH of soil for use in corrosion testing. American Association of State Highway and Transportation Officials, Washington, DC, USA.

AASHTO 1993. AASHTO guide for design of pavement structures. American Association of State Highway and Transportation Officials, Washington, DC, USA. Abdel Hakim, R., El-Badawy, S. M., Gabr, A. G., and Azam, A.M. 2016. Influence of MEPDG unbound material type and material characterization input level on pavement performance. J. of Transportation Research Board, Washington, DC, 2578: 21-28. DOI $10.3141 / 2578-03$.

ARA, Inc., ERES Consultants Division, 2004. Guide for mechanistic-empirical design of new and rehabilitated pavement structures. Prepared for National Cooperative Highway Research Program, NCHRP 1-37A Final Report, Washington, DC, USA.

Alotaibi, A., El-Badawy, S., and Elshabrawy, M. A. 2011. Asphalt pavement recycling as a subbase layer for the Egyptian roads. J. of Environmental Sciences, 40(1): 1-13.

Alam, T. B., Abdelrahman, M., and Schram, S. A. 2010. Laboratory characterisation of recycled asphalt pavement as a base layer. International J. of Pavement Engineering, 11(2): 123-131. doi.org/10.1080/10298430902731362.

Ayres, M. 1997. Development of a rational probabilistic approach for flexible pavements analysis. $\mathrm{PhD}$ Thesis, University of Maryland, USA. 
ASTM D 5856-95. 2007. Measurement of hydraulic conductivity of porous materials using a rigid wall, compaction mold permeameter. ASTM International, West Conshohocken, PA, USA.

Ayan, V. 2011. Assessment of recycled aggregates for use in unbound subbase of highway pavement. PhD Thesis, Kingston University, London, UK.

Azam, A. M., and Cameron, D. A. 2013. Geotechnical properties of blends of recycled clay masonry and recycled concrete aggregates in unbound pavement construction. J. of Materials in Civil Engineering, 25(6): 788-798. DOI: 10.1061/(ASCE)MT.1943-5533.0000634.

Behiry, A. E. A. E.-M., and Elmohr, A. I. 2015. Characterization of recycled asphalt pavement (rap) for use in flexible pavement. American J. of Engineering and Applied Sciences, 8(2): 233-248. DOI: 10.3844/ajeassp.2015.233.248.

Bennert, T., and Maher, A. 2005. The development of a performance specification for granular base and subbase material. Report FHWA-NJ-2005-003, Department of Civil and Environmental Engineering, Center for Advanced Infrastructure \& Transportation (CAIT), Rutgers University, Piscataway, NJ.

Bennert, T., Papp, W.J., Jr., Maher, A., and Gucunski, N. 2000. Utilization of construction and demolition debris under traffic-type loading in base and subbase applications. J. of Transportation Research Board, Washington, DC, 1714: $33-$ 39.DOI: $10.3141 / 1714-05$.

Dong, Q., and Huang, B. 2014. Laboratory evaluation on resilient modulus and rate dependencies of RAP used as unbound base material. J. of Materials in Civil Engineering, 26(2): 379-383. DOI: 10.1061/(ASCE)MT.1943-5533.0000820. 
DPTI (Department for Transport, Energy and Infrastructure) 2011. Part 215 Pavement Materials. Master specification, Division 2, Road Works.

ECP-104. 2008. Egyptian code of practice for urban and rural Roads. Housing and Building National Central Research, Cairo, Egypt.

Garg, N., and Thompson, M. R. 1996. Lincoln avenue reclaimed asphalt pavement base project. J. of Transportation Research Board, Washington, DC, 1547: 89-95. DOI: $10.3141 / 1547-13$.

Gupta, S. C., Kang, D. H., and Ranaivosoon, A. 2009. Hydraulic and mechanical properties of recycled materials. Report 2009-32, Minnesota Department of Transportation, University of Minnesota.

Hicks, R. G. 1970. Factors influencing the resilient properties of granular materials. PhD Thesis, University of California, Berkeley, Calif.

Hicks, R. G., and Monismith, C. L. 1971. Factors influencing the resilient response of granular materials. J. of Transportation Research Board, Washington, DC, 345: 15-31. Huang, Y. H. 2004. Pavement analysis and design. Second Edition, Pearson Prentice Hall, Inc., Englewood Cliffs, New Jersey, USA.

Ji, R., Siddiki, N., Nantung, T., and Kim, D. 2014. Evaluation of resilient modulus of subgrade and base materials in indiana and its implementation in MEPDG. The Scientific World J. 2014.

Kamel, A. M. E. A. 2007. Guidelines for the application of recycled concrete aggregate in the Egyptian construction industry. M.Sc. Thesis, American University in Cairo (AUC), Egypt.

Khan, M. I., Ullah, H., Khan, K. M., Khan, K. U., and Arifuzzaman, M. 2015. Evaluation of speed effect of vehicles on asphalt pavement. Implementing Innovative Ideas in Structural Engineering and Project Management, ISBN: 978-0-9960437-1-7. 
Kim, W., Labuz, J. F., and Dai, S. 2007. Resilient modulus of base course containing recycled asphalt pavement. J. of Transportation Research Board, Washington, DC, 2006: 27-35. DOI. 10.3141/2005-04.

Kolay, P. K., and Singh, P. 2016. Resilient modulus of a blended mixture of recycled asphalt pavement and natural aggregate as road pavement base material. In ASCE Geo-Chicago 2016, Sustainability, Energy, and the Geoenvironment, 677-686.

MacGregor, J. A. C., Highter, W. H., and DeGroot, D. J. 1999. Structural numbers for reclaimed asphalt pavement base and subbase course mixes. J. of Transportation Research Board, Washington, DC, 1687: 22-28.

McGarrah, E. J. 2007. Evaluation of current practices of reclaimed asphalt pavement/virgin aggregate as base course material. Report WA-RD 713.1, Department of Civil and Environmental Engineering, University of Washington, Seattle.

Mokwa, R. L., and Peebles, C. S. 2005. Evaluation of the engineering characteristics of RAP/aggregate blends. Report FHWA/MT-05-008/8117-24, Department of Civil Engineering, Montana State University, Bozeman, MT.

NCHRP, 2004. Guide for mechanistic-empirical design of new and rehabilitated pavement structures. National Research Council, Washington, DC.

Powell, W. D., Potter, J. F., Mayhew, H. C., and Nunn, M. E. 1984. The structural design of bituminous roads. TRRL Laboratory Report LR 1132, Transport and Road Research Laboratory, Crowthorne, United Kingdom.

Sayed, S. M., Pulsifer, J., and Schmitt, R. 1993. Construction and performance of shoulders using UNRAP base. J. of Materials in Civil Engineering, 5(3): 321-338. DOI.org/10.1061/(ASCE)0899-1561(1993)5:3(321). 
Sayed, S. M., Pulsifer, J. M., and Jackson, N. M. 2011. UNRAP: Are we ready for it? J. of Materials in Civil Engineering, 23(2): 188-196. DOI.org/10.1061/(ASCE)MT.1943-5533.0000157.

Seed, H. B., Mitry, F. G., Monismith, C. L., and Chan, C. K. 1965. Predictions of pavement deflections from laboratory repeated load tests. Report TE-65-6, Soil Mechanics. and Bituminous Maerialst. Res. Lab., University of California, Berkeley, California.

Taha, R., Ali, G., Basma, A., and Al-Turk, O. 1999. Evaluation of reclaimed asphalt pavement aggregate in road bases and subbases. J. of the Transportation Research Board, Washington, DC, 1652: 264-269. DOI:10.3141/1652-33.

Thom, N., and Brown, S. 1987. Effect of moisture on the structural performance of a crushed-limestone road base. J. of Transportation Research Board, Washington, DC, 1121: 50-56.

Trzebiatowski, B. D., and Benson, C. H. 2005. Saturated hydraulic conductivity of compacted recycled asphalt pavement. Geotechnical Testing J., 28(5): 1-6.

$\mathrm{Wu}$, M. 2011. Evaluation of high percentage recycled asphalt pavement as base course materials. M.Sc. Thesis, Washington State University, DC, USA.

Wu, M., Wen, H., Muhunthan, B., and Manahiloh K.N. 2012. Influence of RAP content on the air void distribution, permeability and modulus of the base layer in recycled asphalt pavements. J. of the Transportation Research Board, Washington, DC, 2267: 65-71. DOI: 10.3141/2267-07. 


\section{LIST OF TABLES}

Table 1 Basic Engineering Properties of the Blends

Table 2 Regression Parameters of the Universal Model for all Blends

Table 3 Literature Models for Mr Prediction as a Function of CBR/ bulk and/or octahedral shear stress

Table 4 Materials Properties used for KENLAYER Analysis 
Table 1 Basic Engineering Properties of the Blends

\begin{tabular}{|c|c|c|c|c|c|c|c|c|}
\hline \multirow{2}{*}{$\begin{array}{c}\text { Experimental } \\
\text { Test }\end{array}$} & \multirow{2}{*}{ Test Specification } & \multicolumn{6}{|c|}{ Percentage of RAP } & \multirow{2}{*}{$\begin{array}{l}\text { Specification } \\
\text { Limits for the } \\
\text { Base Layer }\end{array}$} \\
\hline & & $\mathbf{0}$ & 20 & 40 & 60 & 80 & 100 & \\
\hline $\mathrm{P} 200, \%$ & AASHTO T 27-99 & 6.40 & --- & --- & --- & --- & 0.90 & $5-15$ \\
\hline $\begin{array}{l}\text { Bulk Specific } \\
\text { Gravity }\end{array}$ & AASHTO T 85-91 & 2.541 & 2.478 & 2.413 & 2.350 & 2.300 & 2.245 & --- \\
\hline $\begin{array}{c}\text { Water } \\
\text { Absorption, \% }\end{array}$ & AASHTO T 85-91 & $1.5^{`}$ & --- & --- & --- & --- & 1.1 & 10 Max. \\
\hline LAA, $\%$ & AASHTO T 96-99 & 25.5 & --- & --- & --- & --- & 31.6 & 50 Max. \\
\hline $\mathrm{LL}, \%$ & AASHTO T 89-96 & 24.4 & --- & --- & --- & --- & --- & 25 Max. \\
\hline PI, \% & AASHTO T 90-00 & 5.3 & --- & --- & --- & --- & $\mathrm{NP}^{\mathrm{b}}$ & 6 Max. \\
\hline $\begin{array}{c}\text { Material } \\
\text { Classification }\end{array}$ & AASHTO M 145-91 & A-l-a & -- & --- & --- & --- & A-1-a & --- \\
\hline $\mathrm{pH}$ & AASHTO T 289-91 & 7.8 & --- & --- & --- & --- & 9.5 & --- \\
\hline $\begin{array}{l}\mathrm{MDD}, \\
\mathrm{gm} / \mathrm{cm}^{3}\end{array}$ & AASHTO T 180-97 & 2.245 & 2.200 & 2.195 & 2.150 & 2.095 & 1.990 & --- \\
\hline $\mathrm{OMC}, \%$ & AASHTO T 180-97 & 7.5 & 7.0 & 6.6 & 6.4 & 6.1 & 6.0 & --- \\
\hline $\begin{array}{l}\text { CBR } 4 \text { days } \\
\text { soaked, } \%\end{array}$ & AASHTO T 193-99 & 84 & 62 & 44 & 27 & 17 & 6 & $\begin{array}{l}60 \text { Min. for } \\
\text { minor and } \\
\text { local roads }\end{array}$ \\
\hline $\begin{array}{l}\text { Permeability, } \\
\mathrm{cm} / \mathrm{sec}\left(10^{-3}\right)\end{array}$ & ASTM D 5856-95 & 191.70 & 100.99 & 80.43 & 49.22 & 15.11 & 5.57 & --- \\
\hline
\end{tabular}

${ }^{\mathrm{a}}$ According to ECP-104, 2008

${ }^{\mathrm{b}}$ Non Plastic 
Table 2 Regression Parameters of the Universal Model for the Investigated Blends

\begin{tabular}{|c|c|c|c|c|c|c|c|c|c|}
\hline $\operatorname{RAP}(\%)$ & $\begin{array}{c}\text { Load } \\
\text { duration }\end{array}$ & $\mathbf{k}_{1}$ & $\mathbf{k}_{2}$ & $\mathbf{k}_{3}$ & $\mathbf{k}_{4}$ & $\mathbf{R}^{2}$ & $\mathbf{R}_{\text {adj }}^{2}$ & $\mathbf{S}_{\mathrm{e}} / \mathbf{S}_{\mathbf{y}}$ & \%RMSE \\
\hline 0 & & 1.82 & 0.35 & 0.45 & --- & 0.986 & 0.983 & 0.120 & 4.33 \\
\hline 20 & & 2.25 & 0.46 & 0.12 & --- & 0.995 & 0.994 & 0.070 & 2.25 \\
\hline 40 & & 2.87 & 0.43 & 0.01 & --- & 0.985 & 0.983 & 0.122 & 3.56 \\
\hline 60 & & 3.21 & 0.34 & 0.235 & --- & 0.993 & 0.992 & 0.083 & 2.23 \\
\hline 80 & & 4.70 & 0.25 & 0.148 & --- & 0.962 & 0.957 & 0.194 & 3.29 \\
\hline 100 & & 5.31 & 0.30 & 0.027 & --- & 0.991 & 0.990 & 0.094 & 1.80 \\
\hline $\begin{array}{c}\text { All Blends } \\
\text { (Equation 1) }\end{array}$ & & 3.34 & 0.33 & 0.174 & --- & 0.376 & 0.369 & 0.790 & 37.92 \\
\hline $\begin{array}{c}\text { All Blends } \\
\text { (Equation 5) }\end{array}$ & & 1.72 & 0.54 & 0.20 & 2.75 & 0.943 & 0.940 & 0.239 & 12.33 \\
\hline $\begin{array}{c}\text { All Blends } \\
\text { (Equation 5) }\end{array}$ & 2 seconds & 0.95 & 0.77 & 0.30 & 2.61 & 0.937 & 0.933 & 0.252 & 12.92 \\
\hline $\begin{array}{c}\text { All Blends } \\
\text { (Equation 5) }\end{array}$ & 3 seconds & 0.47 & 0.83 & 0.77 & 2.39 & 0.905 & 0.900 & 0.309 & 20.28 \\
\hline
\end{tabular}


Table 3 Literature Models for $\mathrm{M}_{\mathrm{r}}$ Prediction as a Function of CBR/ bulk and/or octahedral shear stress

\begin{tabular}{|c|c|c|c|c|c|c|c|c|}
\hline \multirow{2}{*}{ Reference } & \multirow{2}{*}{ Model, (MPa) } & \multirow{2}{*}{$\begin{array}{c}\text { Equation } \\
\text { No. }\end{array}$} & \multicolumn{6}{|c|}{ Percentage of RAP } \\
\hline & & & 0 & 20 & 40 & 60 & 80 & 100 \\
\hline Ayres (1997) & $\mathrm{M}_{\mathrm{R}}=21(\mathrm{CBR})^{0.65}$ & (7) & 375 & 307 & 247 & 179 & 134 & 67 \\
\hline Powell et al (1984) & $\mathrm{M}_{\mathrm{R}}=17.58(\mathrm{CBR})^{0.64}$ & (8) & 300 & 246 & 199 & 145 & 109 & 55 \\
\hline Hicks \& Monismith (1971) & $\mathrm{M}_{\mathrm{R}}=k_{1}(\theta)^{k_{2}}$ & (9) & 306 & 375 & 446 & 491 & 635 & 726 \\
\hline NCHRP (2004) & Universal Model & (1) & 314 & 378 & 446 & 497 & 644 & 727 \\
\hline
\end{tabular}


Table 4 Materials Properties used for KENLAYER Analysis

\begin{tabular}{|c|c|c|c|c|c|}
\hline $\begin{array}{c}\text { \%RAP in Base } \\
\text { Layer }\end{array}$ & $\mathrm{M}_{\mathrm{r}}{ }^{*}, \mathrm{psi}(\mathrm{MPa})$ & $\begin{array}{c}\text { Unit Weight } \\
(\mathrm{pcf})\end{array}$ & $\mathrm{K}_{1}, \mathrm{psi}(\mathrm{MPa})$ & $\mathrm{k}_{2}$ & $\begin{array}{c}\text { Angle of Internal } \\
\text { Friction }(\phi), \\
\text { degrees }\end{array}$ \\
\hline 0 & $44465.2(306.76)$ & 140 & $7651.0(567.0)$ & 0.48 & 56 \\
\hline 20 & $54551.6(376.34)$ & 137 & $8734.7(713.3)$ & 0.50 & 51 \\
\hline 100 & $105356.8(726.88)$ & 124 & $33965.3(1079.2)$ & 0.31 & 39 \\
\hline
\end{tabular}

${ }^{*} \mathrm{M}_{\mathrm{r}}$ values at the anticipated field conditions $\left(\sigma_{1}=24 \mathrm{psi}(0.1655 \mathrm{MPa}), \sigma_{3}=8 \mathrm{psi}(0.0552 \mathrm{MPa})\right)$. 


\section{LIST OF FIGURES}

Figure 1 Particle size distribution of RAP and virgin aggregate

Figure 2 RAP percentage versus the calculated $M_{r}$ at the anticipated field stresses

Figure 3 Predicted versus measured resilient modulus for all blends by the proposed model Figure 4 Resilient modulus versus bulk stress for the $60 \%$ RAP blend at different cycle durations

Figure 5 Effect of load duration and percentage of RAP on resilient modulus

Figure 6 Predicted versus measured resilient modulus for all blends by Equation (6)

Figure 7 Calculated $\mathrm{M}_{\mathrm{r}}$ Versus CBR

Figure 8 Typical cross section with base layer containing 20\% RAP 


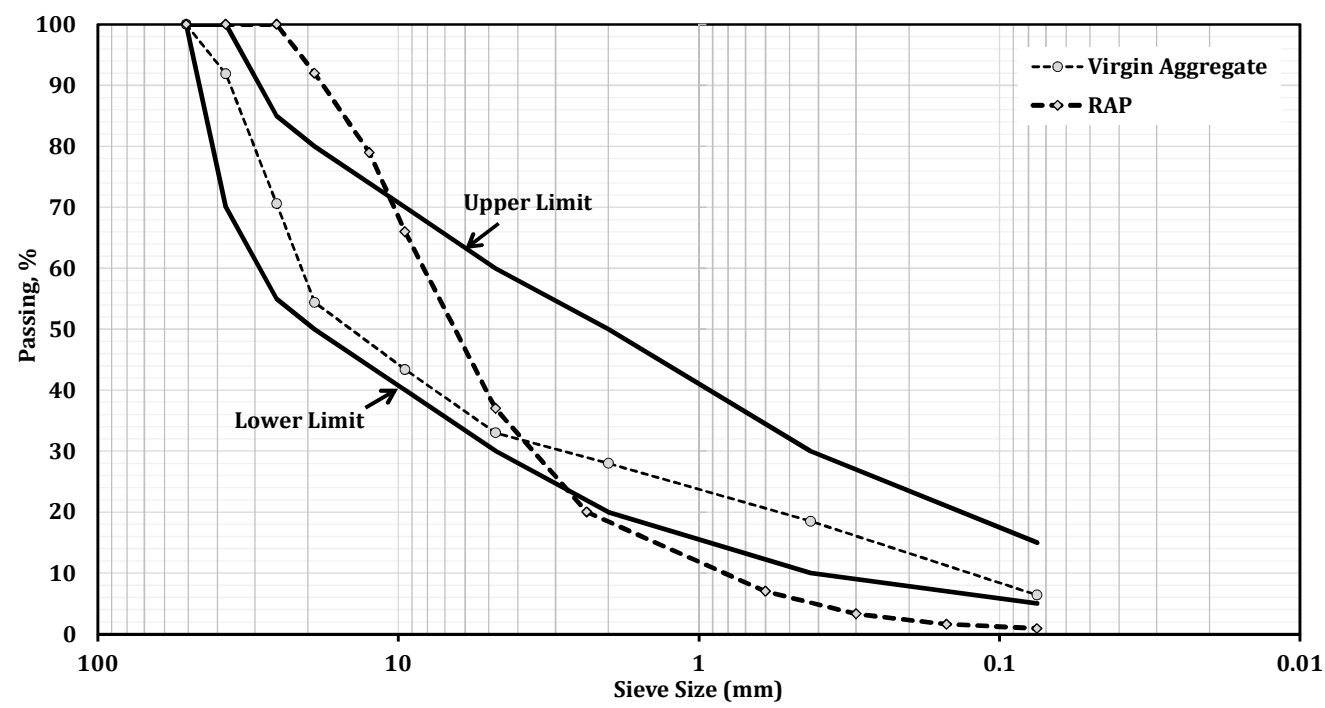

Fig. 1. 


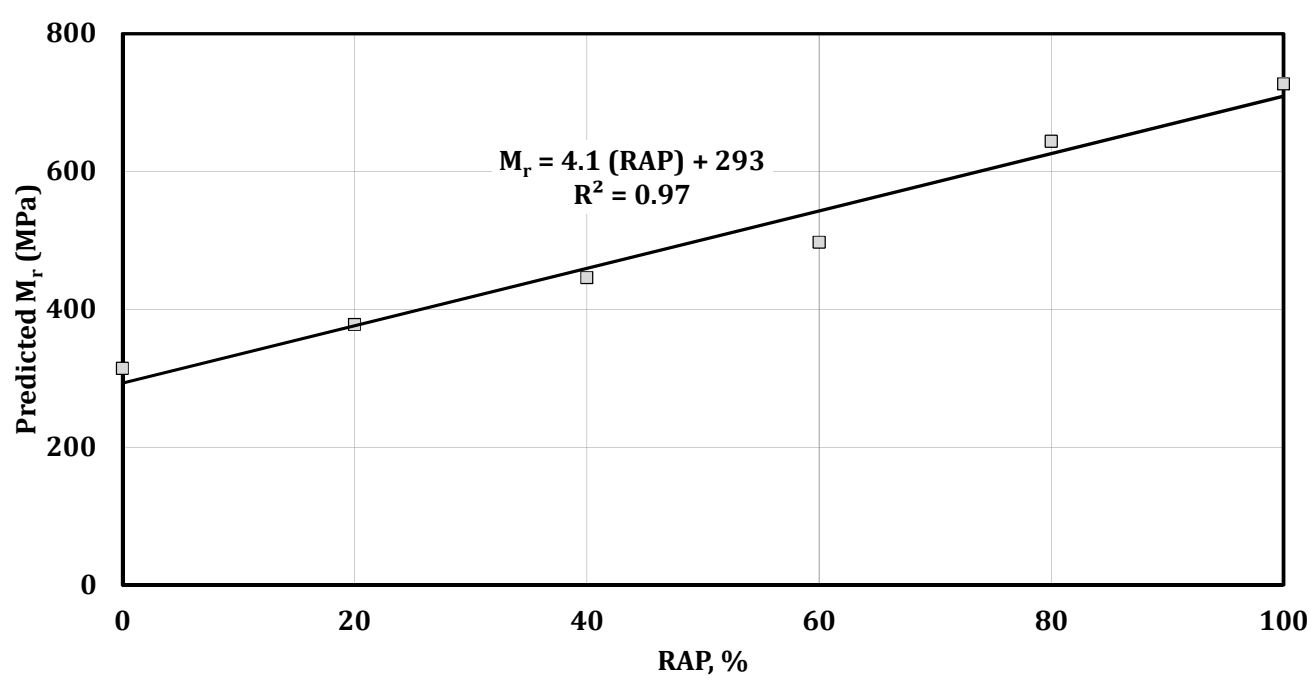

Fig. 2. 


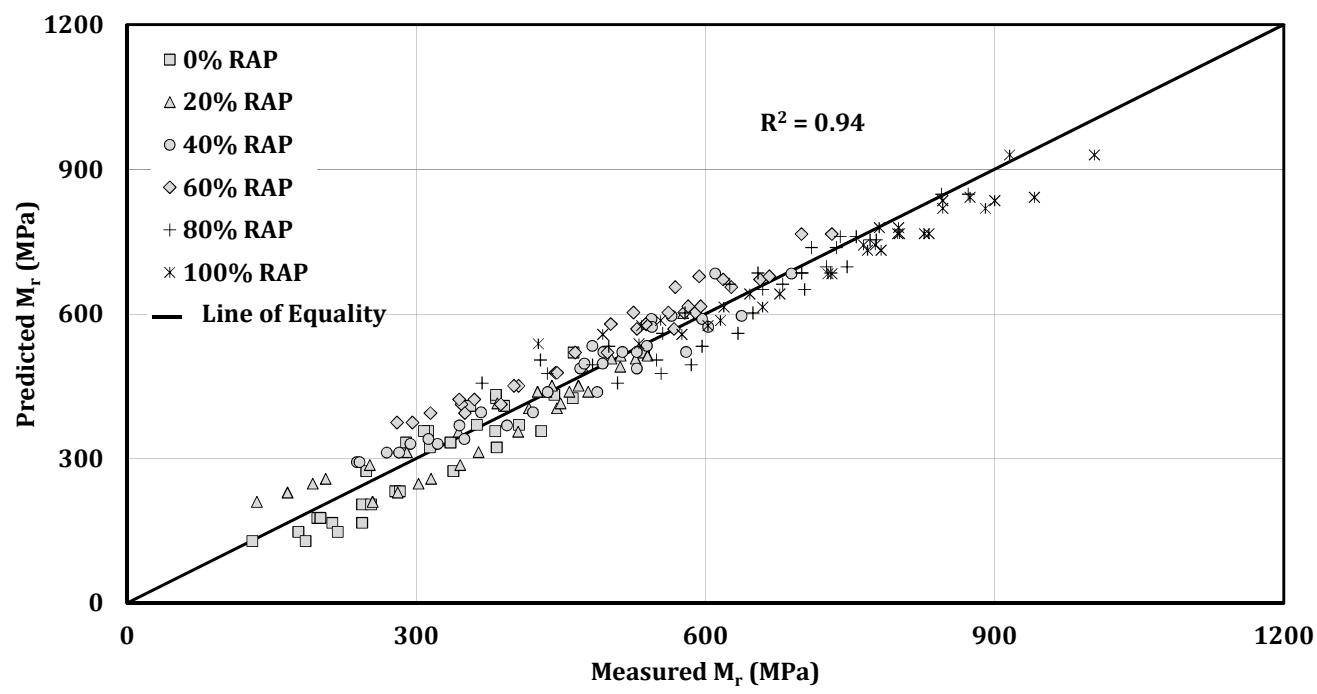

Fig. 3. 


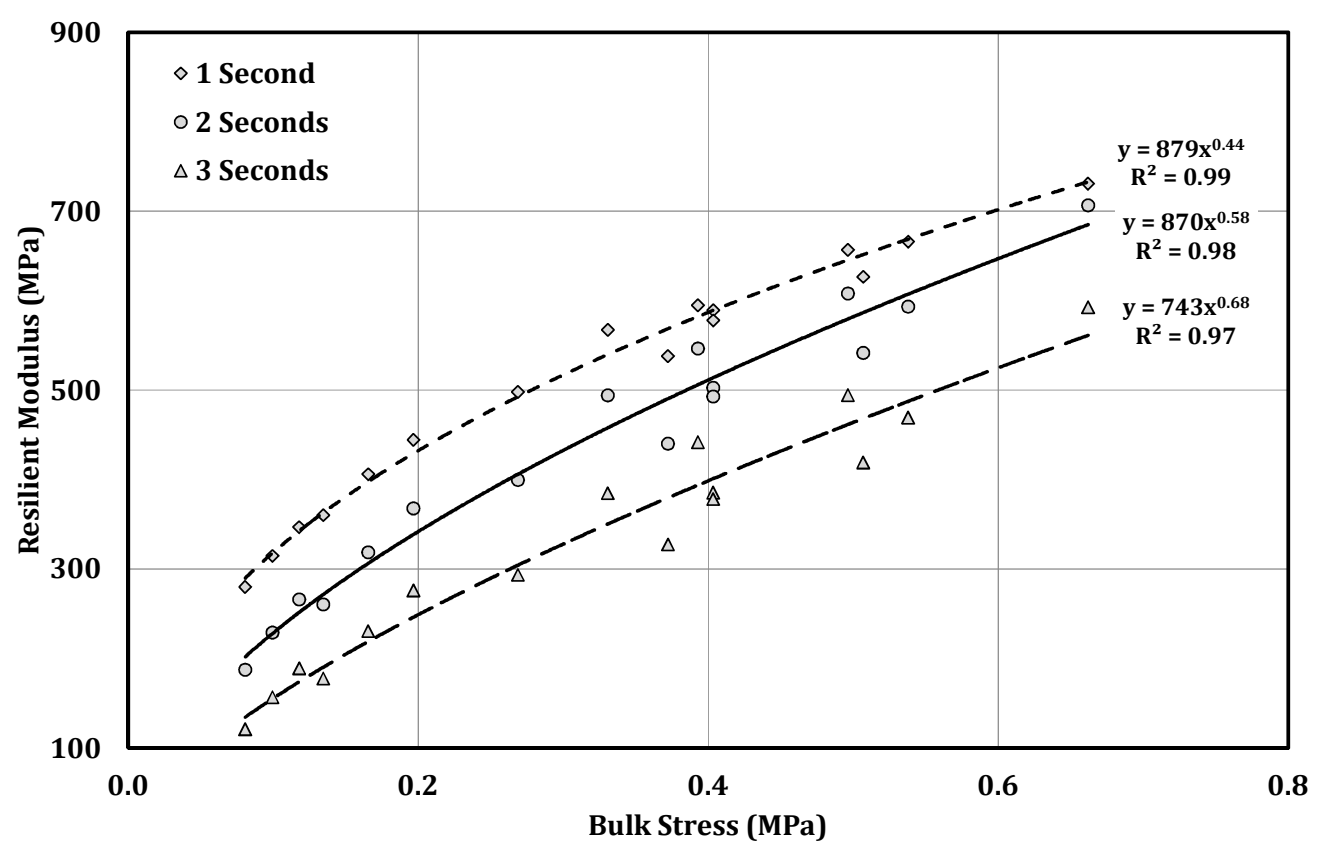

Fig. 4. 


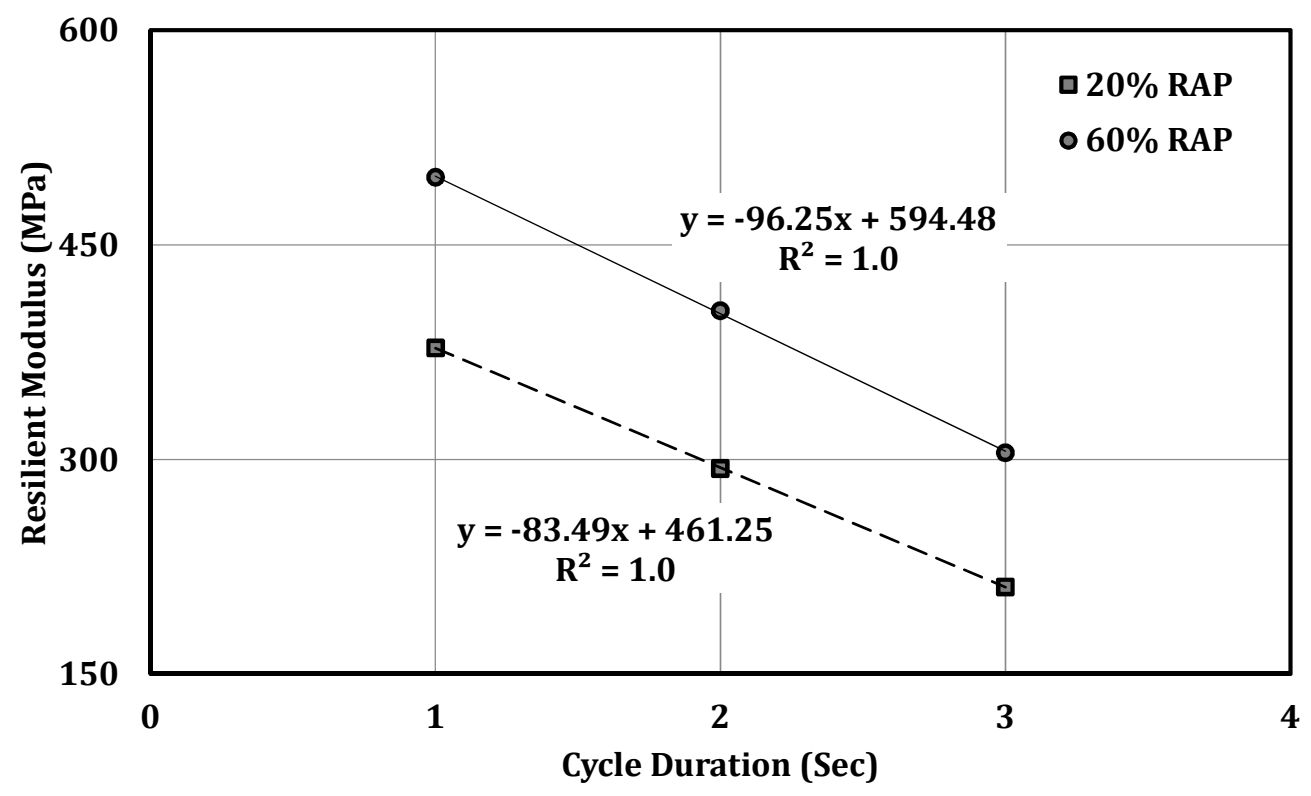

Fig. 5. 


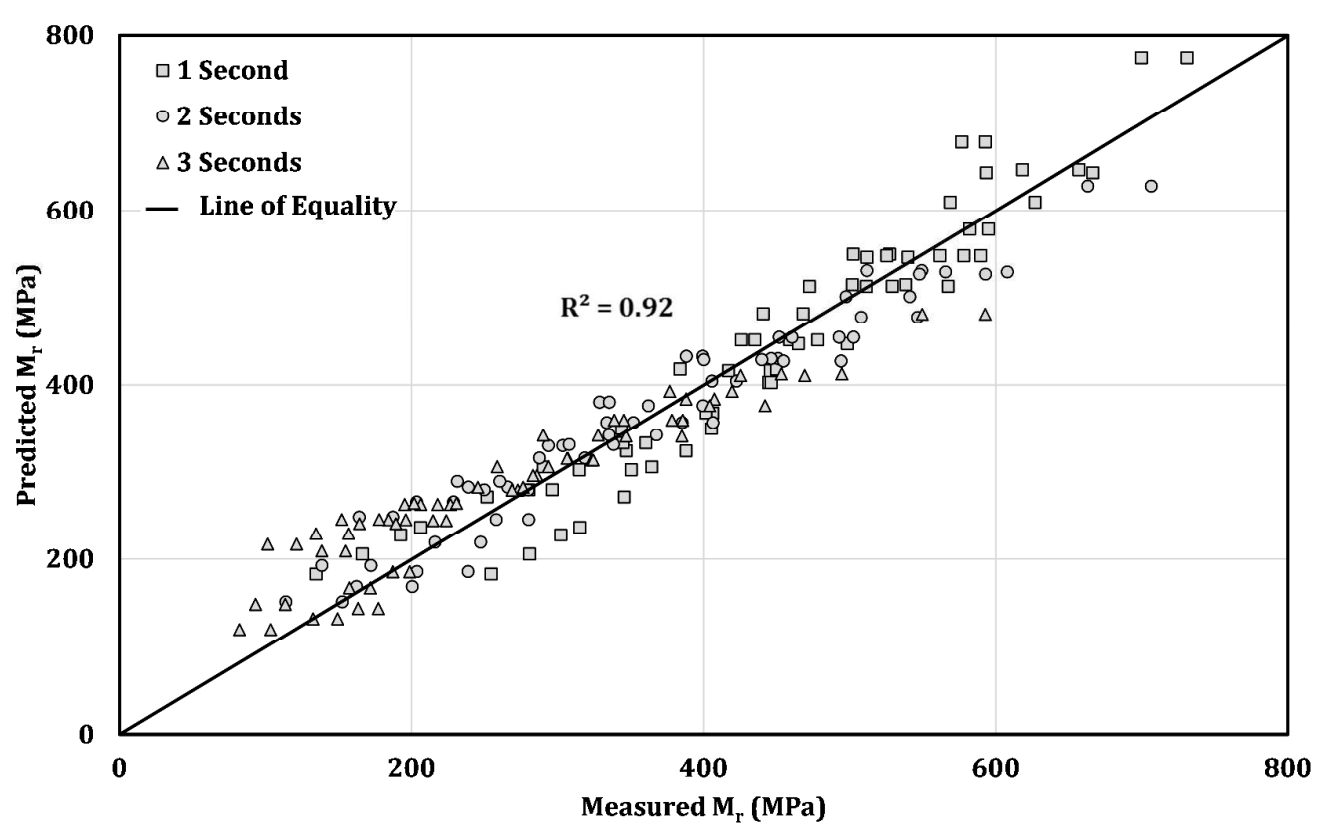

Fig. 6. 


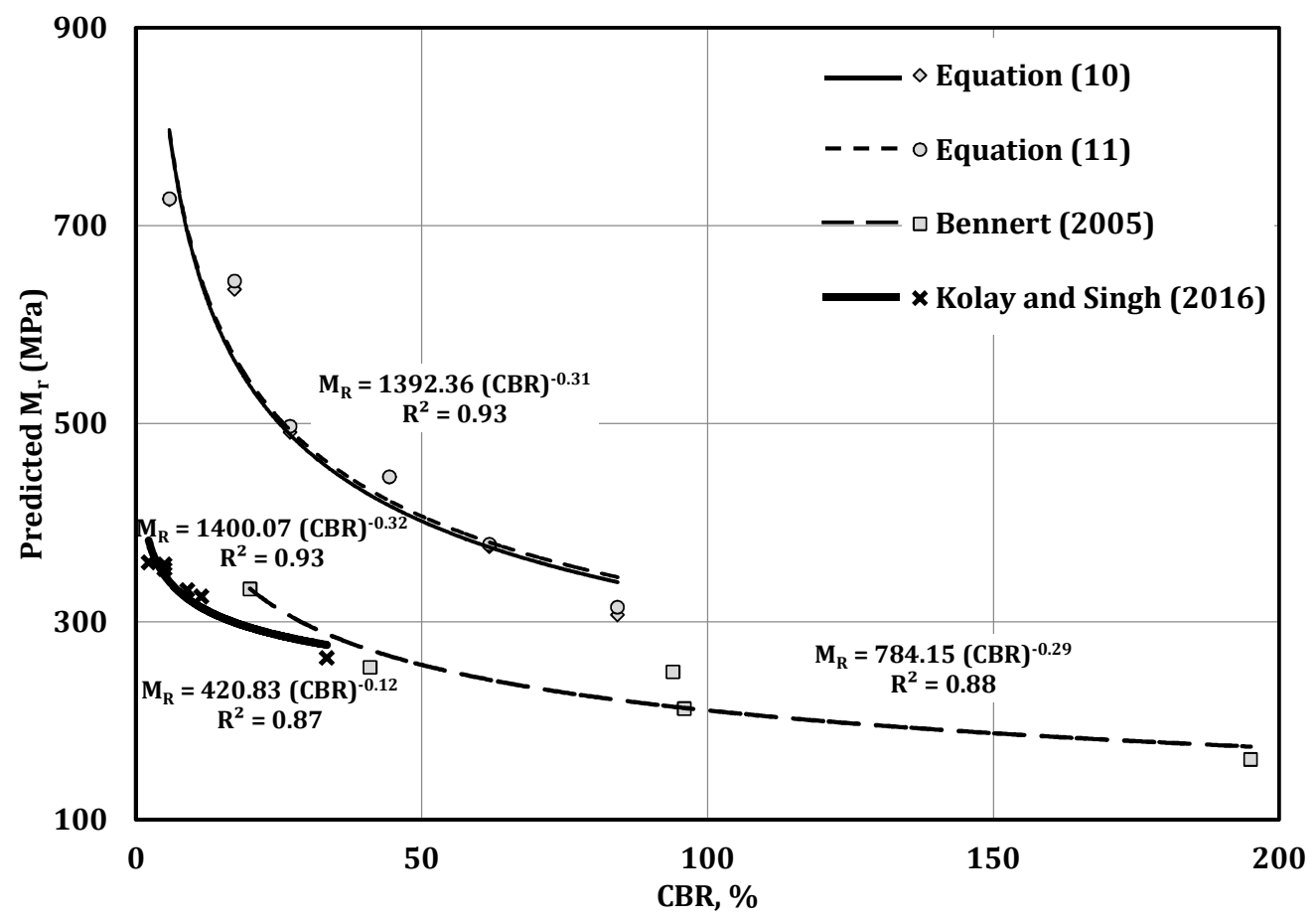

Fig. 7. 


5 in $\begin{gathered}\text { E }=500000 \mathrm{psi} \\ \mathrm{PR}=0.35 \quad \mathrm{GAM}=150 \mathrm{pcf} \\ \mathrm{HMA}\end{gathered}$

Fig. 8. 